\title{
Immunoprevention approaches for cancer prevention
}

\author{
Asad Umar
}

From Updates on Immunotherapy of Cancer and Immunoscore Symposium, part of the Sidra Symposia Series, held in partnership with the Society for Immunotherapy of Cancer

Doha, Qatar. 22-23 January 2014

Here I propose current and future strategies to develop immunoprevention approaches for cancer prevention. A major challenge in the development of effective immunopreventive agents is the recognized requirement for the simultaneous co-development of multiple agents. Infectious agents are linked to approximately $15 \%$ to $20 \%$ of all cancers worldwide. Viruses are the infectious agents most commonly associated with cancer causation but bacteria and parasites may also have a carcinogenic effect. Oncoviruses include human papillomavirus (cervical and other cancers), Epstein-Barr virus (B-cell lymphoproliferative disease and nasopharyngeal carcinoma), Kaposi's sarcoma-associated herpesvirus (Kaposi's sarcoma and primary effusion lymphomas), hepatitis B and hepatitis $C$ viruses (hepatocellular carcinoma), and human T-lymphotropic virus-1 (adult T-cell leukemia/ lymphoma). Current progress and our development of these areas include prophylactic vaccines (general naïve population to prevent infection in the first place) (e.g., HPV, HBV, HCV etc.) and therapeutic vaccines (treating already infected individuals with an intent to delay or prevent cancer onset) (e.g., HPV, EBV, HBV, HCV, and H. pylori etc.).

Published: 24 February 2014

doi:10.1186/2051-1426-2-S1-P7

Cite this article as: Umar: Immunoprevention approaches for cancer prevention. Journal for ImmunoTherapy of Cancer 2014 2(Suppl 1):P7.
Submit your next manuscript to BioMed Central and take full advantage of:

- Convenient online submission

- Thorough peer review

- No space constraints or color figure charges

- Immediate publication on acceptance

- Inclusion in PubMed, CAS, Scopus and Google Scholar

- Research which is freely available for redistribution
() Biomed Central 